\title{
STUDY AND EVALUATION OF ANTIMICROBIAL ACTIVITY AND ANTIOXIDANT CAPACITY OF DRY EXTRACT AND FRACTIONS OF LEAVES OF Raphanus sativus var. oleiferus Metzg.
}

\author{
ESTUDO QUÍMICO E AVALIAÇÃO DA ATIVIDADE ANTIMICROBIANA E DA \\ CAPACIDADE ANTIOXIDANTE DO EXTRATO SECO E FRAÇÕES DE FOLHAS DE \\ Raphanus sativus var. oleiferus Metzg.
}

\begin{abstract}
Ana Flavia da SILVA ${ }^{1, ~}$; Marisa de Oliveira LOPES $^{\mathbf{1}}$; Claudio Daniel CERDEIRA ${ }^{\mathbf{1}}$; Ingridy Simone RIBEIRO²; Isael Aparecido ROSA ${ }^{4}$; Jorge Kleber CHAVASCO²; Marcelo Aparecido da SILVA ${ }^{\mathbf{1}}$; Marcos José MARQUES ${ }^{\mathbf{3}}$; Geraldo Alves da SILVA ${ }^{\mathbf{1}}$
\end{abstract}

1. Department of Food and Drugs, School of Pharmaceutical Sciences, Federal University of Alfenas, UNIFAL, Alfenas, Minas Gerais, Brazil. afsfarma@hotmail.com*; 2. Department of Microbiology and Immunology and Pathology, Institute of Biomedical Sciences, Federal University of Alfenas, UNIFAL, Alfenas, Minas Gerais, Brazil; 4. Department of Chemistry, Federal University of Lavras, UFLA, Lavras, Minas Gerais, Brazil.

\begin{abstract}
The radish (Raphanus sativus L.) is a vegetable of the Brassicaceae family cultivated worldwide and has several medicinal properties. Its biological activities are related to various secondary metabolites present in the species, especially phenolics. Thus, the objectives of this study were the chemical analysis and evaluation of the antioxidant and antimicrobial activities of the dry extract and fractions of the fodder turnip leaves ( $R$. sativus var. oleiferus Metzg.). Samples were analyzed by mass spectrometry and the antioxidant activity was evaluated using the 2,2-diphenyl-1-picrylhydrazyl (DPPH) radical method and the reducing power method. Antimicrobial activity was determined by the agar diffusion and microdilution methods. The total phenols were concentrated in the butanol fraction (121.27 $\mathrm{mg} \mathrm{GAE} / \mathrm{g})$ and the flavonoids were concentrated in the ethyl acetate fraction $(98.02 \mathrm{mg} \mathrm{EQ} / \mathrm{g})$. The ethyl acetate fraction showed the best antioxidants results, with $83.45 \%$ of free radical scavenging and $11.34 \%$ of ferric ions reduction. The analysis of antimicrobial activity showed that the dry extract had the highest average zone of inhibition against Bacillus subtilis $(18.67 \mathrm{~mm})$. Smaller values of the minimum inhibitory concentration for Micrococcus luteus were, and the ethyl acetate fraction showed a lower minimum inhibitory concentration $(0.1 \mathrm{mg} / \mathrm{ml})$ for that microorganism. There was a strong correlation between the antioxidant activity and the content of phenols and flavonoids. The results showed the potential antioxidant and antimicrobial activities of this extract with the ethyl acetate fraction being most promising for further studies.
\end{abstract}

KEYWORDS: Fodder turnip. Phenolic compounds. Brassicaceae. Medicinal plants.

\section{INTRODUCTION}

The use of plants for medicinal purposes is an old practice and is associated with popular knowledge from different parts of the world (VEIGA; PINTO; MACIEL, 2005). The study of the chemical composition of plants indicates their potential biological properties and can encompass both the therapeutic and toxicological properties (SOUZA-MOREIRA; SALGADO; PIETRO, 2010).

The discovery of new plant products can significantly contribute to global health, as well as providing alternative therapeutic approaches. There is also the possibility of isolating substances with greater efficacy, lower cost, lower toxicity, milder side effects and greater availability of the raw material (MENEZES et al., 2009).

The Brassicaceae family has about 350 genera and 4000 species, originating in the northern hemisphere and distributed in temperate zones around the New World (ZECCA, 2008). Several horticultural varieties are found, especially Brassica oleracea var. acephala (kale), B. oleracea var. capitata (cabbage), B. oleracea var. borytis (cauliflower), B. oleracea var. italica (broccoli), $B$. nigra and Sinapis sp. (mustard), Raphanus sativus L. var. radicle (radish) and Eruca sativa (arugula) (SOUZA; LORENZI, 2005).

The common radish ( $R$. sativus L.) is a vegetable root crop with numerous varieties, among them: radicle, niger, mougri and oleifera (GUTIERREZ; PEREZ, 2004; ARUNA; YERRAGUNI; RAJU, 2012). Different parts of the plant (leaves, seeds and roots) are used in folk medicine for gastrointestinal disorders and biliary, liver, urinary, respiratory and cardiovascular ailments (DEVARAJ; KRISHNA; VISWANATHA, 2011; SHIN et al., 2015). In addition, the plant 
contains bioactives with anti-inflammatory (PARK; SONG, 2017; MANIVANNAN et al., 2019), antimicrobiana, antioxidante, antimutagênica (GUTIERREZ and PEREZ, 2004; ALQASOUMI; AI-HOWIRINY; RAFATULLAH, 2008; SHIN et al., 2015; LUO et al., 2018; MANIVANNAN et al., 2019), antiviral (GUTIERREZ; PEREZ, 2004; SHIN et al, 2015; PARK et al., 2017) e antidiabética (BANIHANI, 2017; MANIVANNAN et al., 2019) properties. The major secondary metabolites of the species are polyphenols, flavonoids, alkaloids, tannins, volatile oils and glycosinolates (ARUNA; YERRAGUNI; RAJU, 2012). However the flavonoids are undoubtedly are the largest group of bioactive chemicals (JAHANGIR et al., 2009).

$R$. sativus var. oleiferus Metzg., popularly known as fodder turnip, is a variety of radish little studied from the chemical and biological point of view. Therefore, this study aimed to perform chemical analysis and to evaluate the antioxidant and antimicrobial potential of fodder turnip, in order to correlate the main chemical constituents detected with the biological activities.

\section{MATERIAL AND METHODS}

\section{Plant material}

The leaves of fodder turnip were collected in June 2013, on a plot situated at Avenida Afonso Pena, the city of Alfenas (latitude $21^{\circ} 25^{\prime} 22.87^{\prime \prime S}$, longitude $45^{\circ} 57^{\prime} 29.42^{\prime \prime W}$ ), Minas Gerais, Brazil. The climate of the site at the time was cold and dry, with an average temperature of $14^{\circ} \mathrm{C}$. The identity of the plant was confirmed by Prof. Dr. Geraldo Alves da Silva. A voucher specimen of the plant material was deposited in the Herbarium of the Federal University of Alfenas and registered under number 2279.

\section{Preparation of the dry extract and fractions}

The leaves were dried in an oven with air circulation at $45{ }^{\circ} \mathrm{C}$ for 72 hours and then pulverized. Three hundred grams of plant material was submitted to the percolation method (PRISTA; ALVES; MORGADO, 1992) using a mixture of ethanol: water $(7: 3, \mathrm{v} / \mathrm{v})$ as liquid extactor. Subsequently, the extract obtained was concentrated on a rotaevaporator and finally dried by lyophilization, with a final yield of $29.198 \%$. Ten grams of the dry extract was solubilized in water and subjected to a process of liquid-liquid extraction with increasingly polar solvents. After extraction and removal of the organic solvent the hexane (FrHex), ethyl acetate (FrAcOEt), butanol $(\mathrm{FrBuOH})$ and aqueous (FrAq) fractions were obtained. The yields from each fraction compared to the initial amount of dry extract were $10.26 \%$, $5.88 \%, 30.40 \%$ and $22.12 \%$, respectively.

\section{Analysis by mass spectrometry with electrospray ionization (ESI-MS)}

Mass spectra were obtained using an LTQ XL Linear Thermo Scientific 2D mass spectrometer, equipped with direct insertion of the sample via continuous flow injection (FIA). The extract and the fractions were analyzed in electrospray ionization mode (ESI) with fragmentation in multiple stages held in an ion trap type interface (IT). Negative mode was selected for the generation and analysis of the first-order mass spectra (MS) as well as for other experiments in multiple stages $\left(\mathrm{MS}^{\mathrm{n}}\right)$ using the following conditions: capillary voltage of $-41 \mathrm{~V}$ voltage spray $-5 \mathrm{kV}$, capillary temperature $280{ }^{\circ} \mathrm{C}$, carrier gas $\left(\mathrm{N}_{2}\right)$ flow 60 (arbitrary units). The track acquisition was $m / z$ 50-2000 with two or more sweep events performed simultaneously in the LTQ XL mass spectrometer.

\section{Determination of total phenols}

The total phenolic content was determined by the colorimetric method of Folin-Ciocalteau (SINGLETON; ORTHOFER; LAMUELARAVENTOS, 1999). The samples were dissolved in ethanol $(500 \mu \mathrm{g} / \mathrm{ml})$ and $0.5 \mathrm{~mL}$ of each solution was added to $2.5 \mathrm{~mL}$ Folin-Ciocalteu reagent $10 \%$ (v/v). They were then added to $2.0 \mathrm{~mL}$ sodium carbonate $\left(\mathrm{Na}_{2} \mathrm{CO}_{3}\right) 4 \%(\mathrm{w} / \mathrm{v})$. The absorbance was measured in a spectrophotometer at $750 \mathrm{~nm}$. The standard used to construct the calibration curve was gallic acid in concentrations from 5 to $100 \mu \mathrm{g} / \mathrm{mL}$. The results were expressed in $\mathrm{mg}$ of GAE (gallic acid equivalents) per gram of sample.

\section{Determination of total flavonoid}

The flavonoid content was determined by a colorimetric method using an aluminum chloride reagent (KALIA et al., 2008). The samples were dissolved in ethanol $(1000 \mu \mathrm{g} / \mathrm{mL})$ and $0.5 \mathrm{~mL}$ of each solution was added to $0.1 \mathrm{~mL}$ aluminum chloride $\left(\mathrm{AlCl}_{3} \cdot 6 \mathrm{H}_{2} \mathrm{O}\right) 10 \%(\mathrm{w} / \mathrm{v})$ and to $0.1 \mathrm{~mL}$ of potassium acetate $\left(\mathrm{CH}_{3} \mathrm{COOK}\right) 1 \mathrm{M}(\mathrm{w} / \mathrm{v})$. The absorbance was measured in a spectrophotometer at $425 \mathrm{~nm}$. The standard used to construct the calibration curve was quercetin in a concentration range of 5 to $100 \mu \mathrm{g} / \mathrm{mL}$. The results were expressed in $\mathrm{mg}$ of $\mathrm{EQ}$ (quercetin equivalents) per gram of sample. 


\section{Evaluation of antiradical activity}

The antiradical activity was determined based on the 2,2-diphenyl-1-picrylhydrazyl (DPPH) radical scavenging method (YEN; CHANG; DUH, 2005). The samples and standards (ascorbic acid and BHT) were dissolved in ethanol $(25-400 \mu \mathrm{g} / \mathrm{mL})$ and $2.0 \mathrm{~mL}$ of each solution was added to $0.5 \mathrm{~mL}$ DPPH (2, 2-diphenyl-1-picrylhydrazyl) solution (0.5 $\mathrm{mM})$. The absorbance was measured at $517 \mathrm{~nm}$ and the results were expressed as percentages of DPPH radical scavenged.

\section{Assessment of reducing power}

The reducing power of the samples was measured according to previously described methods (YILDRIM et al., 2001a; YILDRIM et al., 2001b). The samples and standards (quercetin, ascorbic acid and BHT) were dissolved in ethanol $(25-400 \mu \mathrm{g} / \mathrm{mL})$. To $2.0 \mathrm{~mL}$ of each solution was added $2.5 \mathrm{~mL}$ phosphate buffer $0.2 \mathrm{M}$ (pH 6.6), 2.5 $\mathrm{mL}$ potassium ferricyanide $\left(\mathrm{K}_{3}\left[\mathrm{Fe}\left(\mathrm{CN}_{6}\right)\right]\right)(1 \% \mathrm{w} / \mathrm{v})$ and $2.5 \mathrm{~mL}$ trichloroacetic acid $(10 \% \mathrm{w} / \mathrm{v})$. To 2.5 $\mathrm{mL}$ of this mixture was added $0.5 \mathrm{~mL}$ ferric chloride $\left(\mathrm{FeCl}_{3}\right) 0.1 \%$ w/v. The absorbance was measured at $700 \mathrm{~nm}$ and the results were expressed as the percentages of ferric ions reduction.

\section{Evaluation of antimicrobial activity}

The dry extract and the fractions were dissolved in dimethyl sulfoxide (DMSO) (50 $\mathrm{mg} / \mathrm{mL}$ ) and antimicrobial activity was assessed according to the agar diffusion method according to the methodology proposed in the documents M7-A6 (CLSI, 2003) for bacteria, M24-A2 (CLSI, 2011) for mycobacteria and M44-A2 (CLSI, 2009) for fungi. The microorganisms used consisted of Gramnegative bacteria: Escherichia coli (ATCC 25922), Pseudomonas aeruginosa (ATCC 27853), Proteus mirabilis (ATCC 25922), Salmonella tiphy (ATCC 14028), Enterobacter cloacae LMI-Unifal; Grampositive bacteria: Enterococcus faecalis (ATCC 51299), Micrococcus luteus (ATCC 9341), Bacillus subtilis (ATCC 6633), Staphylococcus aureus (ATCC 6538), Bacillus cereus (ATCC 11778); Fungi: Candida albicans (ATCC 10231) and Saccharomyces cerevisiae (ATCC 2601) and mycobacteria: Mycobacterium tuberculosis (ATCC 25177) (H37Ra) and Mycobacterium bovis (BCG sample). The chlorhexidine $0.12 \%$ was used as positive control and the distilled water as negative control.

The minimum inhibitory concentration (MIC) was determined in samples that inhibited microbial growth in the agar diffusion test, according to the document M27A3 (CLSI, 2008). The tests were performed in sterile 96-well microplates. The dry extract and the fractions were dissolved in DMSO to obtain initial concentration of $25 \mathrm{mg} / \mathrm{mL}$. From this stock solution, serial dilutions were performed to achieve a concentration of 0.025 $\mathrm{mg} / \mathrm{mL}$.

\section{Evaluation of cytotoxicity}

Peritoneal murinos macrophages were maintained in RPMI 1640 to $37^{\circ} \mathrm{C}$ and $5 \% \mathrm{CO}_{2}$, arranged in 24 wells in the ratio $8 \times 10^{5}$ per well, to which were added the extract and fractions to be evaluated in various concentrations ( 0.1 to 160 $\mu \mathrm{g} / \mathrm{mL}$ ) and incubated for 72 hours. After the incubation period were added $50 \mu \mathrm{l}$ of MTT (3-(4,5dimethylthiazol-2-yl )-2,5diphenyltetrazolium bromide) to each well, with new incubation for 4 hours. The cells were lisadas with DMSO and evaluated in UV/VIS spectrophotometer Shimadzu, double-beam, 2550 model to $570 \mathrm{~nm}$ compared to the control without adding drugs (PEREIRA et al., 2010).

\section{Statistical analysis}

The experiments were performed in triplicate and the mean and standard deviation of the results were determined. Values were submitted to analysis of variance (ANOVA) followed by Scott and Knott (1974) test $(P<0.05)$. Correlation analyses were assessed using Spearman correlation coefficients (r).

\section{RESULTS AND DISCUSSION}

In chemical analyses by mass spectrometry, it was found that compounds of molecular masses 564, 578, 594 and $610 \mathrm{~g} / \mathrm{mol}$ (Figure 1) are common to the extract and all fractions, but with different intensities in each. These compounds probably correspond to flavonoids that were deprotonated and recorded as their respective ions ([M-H] $\left.]^{-}\right)$(GATES; LOPES, 2012). Fragmentations in multiple stages $\left(\mathrm{MS}^{\mathrm{n}}\right)$ were obtained for these ions, which made it possible to propose their molecular structures based on the literature and likely fragmentation mechanisms.

Analyzing the data in $\mathrm{MS}^{2}$ (Table 1), it was observed that the fragmentation of the ion with $\mathrm{m} / \mathrm{z} 609$ ([M-H] $\left.]^{-}\right)$resulted in a base peak of $\mathrm{m} / z 447$ and another peak of $\mathrm{m} / \mathrm{z} 463$, suggesting the loss of mass 162 (hexose) and 146 (6-deoxy-hexose) sugars, respectively (WOLFENDER et al. 1992; GATES; LOPES, 2012). 


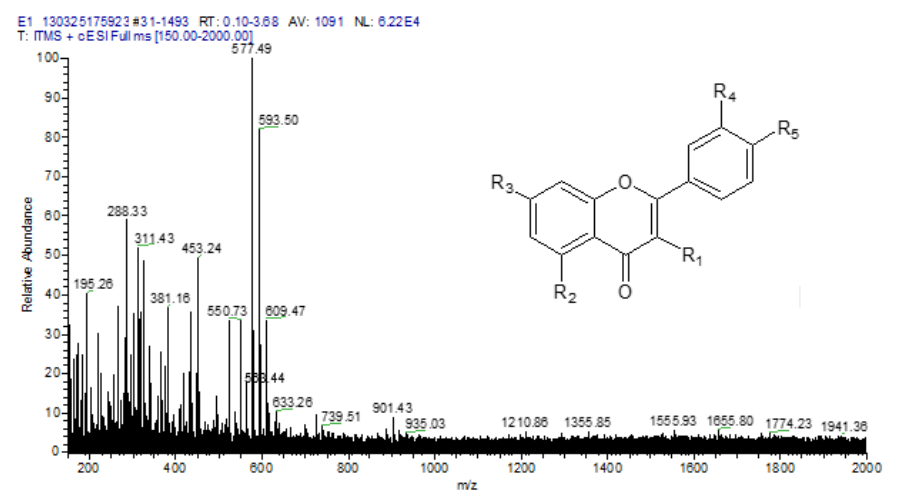

Figure 1. Spectrum mass in full scan mode, obtained by direct injection of dry extract.

The ion of $m / z 593\left([\mathrm{M}-\mathrm{H}]^{-}\right)$showed a base peak of $\mathrm{m} / \mathrm{z}$ 447, which is likely to be due to the loss of a sugar of mass 146 (6-deoxy-hexose) (WOLFENDER et al., 1992; RANA et al., 2015). The peak with $\mathrm{m} / \mathrm{z} 301$ is the aglycone quercetin (SUN et al., 2007; DEVARAJI; KRISHNA; VISWANATHA, 2011; GATES; LOPES, 2012; RANA et al., 2015; VALLVERDÚ-QUERALT et al., 2015), formed after the loss of sugars. In the $\mathrm{MS}^{2}$ spectrum the ion of $\mathrm{m} / \mathrm{z} 577$ ([M-H]') observed with a base peak at $m / z, 431$ and another peak at $\mathrm{m} / \mathrm{z}$ 285 may result from the loss of one and two sugar molecules of mass 146 (6-deoxy-hexose), respectively (WOLFENDER et al., 1992; ZANUTTO et al., 2013; RANA et al., 2015). The ion with $\mathrm{m} / \mathrm{z} 563\left([\mathrm{M}-\mathrm{H}]^{-}\right)$showed a base peak of $\mathrm{m} / z, 417$ and another peak of $m / z 430$, which may be the result of loss of a sugar of mass 146 (6-deoxy- hexose) and a mass 132 sugar (pentose), respectively (WOLFENDER et al., 1992). The peak with $\mathrm{m} / \mathrm{z} 285$ corresponds to the aglycone kaempferol (SUN et al., 2007; DEVARAJ; KRISHNA; VISWANATHA, 2011; RANA et al., 2015; VALLVERDÚ-QUERALT et al., 2015) formed after the loss of sugar molecules.

Generally, radishes are characterized by a high content of phenolic compounds, including the flavonoids quercetin and kaempferol (SHIN et al., 2015; KIM; BASKAR; PARK et al., 2016; RICARDO et al., 2018; IYDA et al., 2019). Other compounds such as, alkaloids, glycosinolates, pigments and proteoglycans may also be present and exhibit antimicrobial, antioxidant, antitumor and antiviral activities (ARUNA; YERRAGUNI; RAJU, 2012; SHIN et al., 2015).

Table 1. Proposed structures of some flavonoids found in dry extract and the fractions.

\begin{tabular}{cccccccl}
\hline Flavonoids & $\mathrm{R}_{1}$ & $\mathrm{R}_{2}$ & $\mathrm{R}_{3}$ & $\mathrm{R}_{4}$ & $\mathrm{R}_{5}$ & {$[\mathrm{M}-\mathrm{H}]^{-}$} & Fragments main \\
\hline 1 & $\mathrm{O}-\mathrm{hex}$ & $\mathrm{OH}$ & O-6-dhex & $\mathrm{OH}$ & $\mathrm{OH}$ & 609 & $463,447,301$ \\
2 & $\mathrm{OH}$ & $\mathrm{OH}$ & O-6-dhex & $\mathrm{H}$ & O-6-dhex & 593 & 447,301 \\
3 & $\mathrm{H}$ & $\mathrm{OH}$ & O-6-dhex & $\mathrm{OH}$ & O-6-dhex & 577 & 431,285 \\
4 & $\mathrm{OH}$ & $\mathrm{OH}$ & O-6-dhex & $\mathrm{H}$ & pent & 563 & $417,430,285$ \\
\hline
\end{tabular}

Legend: hex (hexose); pent (pentose); 6-dhex (deoxy-hexose).

The phenol contents (Table 2) were higher in the fractions obtained after the concentration of the dry extract, and were most concentrated in the butanol fraction. The flavonoid contents were also higher in the fractions than in the dry extract except for the aqueous fraction, and were most concentrated in the ethyl acetate fraction. Chorol (2019) in his study with methanolic and acetonic extracts from R.sativus L. leaves obtained phenolic compound concentrations of $20 \mathrm{mg}$ GAE/g e $3.6 \mathrm{mg}$ $\mathrm{GAE} / \mathrm{g}$, respectively. Lower values than the values obtained in this work.
Phenolic compounds and vitamin $\mathrm{C}$ are found in higher amounts in antioxidant Brassicaceae family plants (PODSEDEK, 2007). Flavonoids are reducing agents which can act to capture and neutralize oxidizing species, acting synergistically with other antioxidants such as vitamins $\mathrm{C}$ and $\mathrm{E}$. The capacity of flavonoids to chelate metals also prevents these acting as catalysts in the formation of free radicals (SILVA; VALE; FELÍCIO, 2015). This suggests the protective role of these metabolites in reducing the risk of cardiovascular disease and other diseases associated with the formation of free radicals (PEREIRA; CARDOSO, 2012). 
Table 2. Total phenolic and flavonoid content of dry extract and fractions of leaves of R. sativus var. oleiferus

\begin{tabular}{lcr}
\hline Samples & $\begin{array}{c}\text { Total phenols content } \\
(\text { mg GAE/g of sample) } *\end{array}$ & $\begin{array}{r}\text { Total flavonoid co } \\
(\mathrm{mg} \mathrm{QE} / \mathrm{g} \text { of samp }\end{array}$ \\
\hline EF & $47,02 \pm 0,6^{\mathrm{a}}$ & $20,36 \pm 0,6^{\mathrm{b}}$ \\
FrHex & $96,09 \pm 3,1^{\mathrm{c}}$ & $70,93 \pm 0,4^{\mathrm{c}}$ \\
FrAcOEt & $99,95 \pm 1,4^{\mathrm{c}}$ & $98,02 \pm 0,2^{\mathrm{e}}$ \\
FrBuOH & $121,27 \pm 1,1^{\mathrm{d}}$ & $89,87 \pm 0,6^{\mathrm{d}}$ \\
FrAq & $52,48 \pm 0,3^{\mathrm{b}}$ & $3,28 \pm 0,4^{\mathrm{a}}$
\end{tabular}

Legend: EF: dry extract of the leaves; FrHex: hexane fraction; FrAcOEt: ethyl acetate fraction; FrBuOH: butanol fraction; FrAq: aqueous fraction; GAE: gallic acid equivalents; QE: quercetin equivalents.

\section{Evaluation of the antioxidant activity}

Among the samples analyzed in this work, it was observed that the ethyl acetate fraction presented higher antioxidant capacity (Table 3), possibly due to the higher flavonoid content (Table 2). In addition, the ethyl acetate fraction presented a percentage of free radical sequestration close to the standards of quercetin and ascorbic acid, demonstrating the potential of this fraction. Goyeneche et al. (2015) demonstrated in their study that the leaves of $R$. sativus $\mathrm{L}$. presented a four times higher concentration of flavonoids in relation to the root, showing an excellent antioxidant capacity. The increase of the activity as a function of the concentration of these compounds was also evidenced in the study of Park et al. (2016) carried out with three cultivars of radish. Eveline and Pasau (2019) determined that the ethyl acetate would be the best type of solvent for the extraction of bioactive compounds in radishes, due to higher flavonoid concentrations and to a higher capability of neutralization of free radicals obtained.

Table 3. Antirradicalar activity and reducing power (to $100 \mu \mathrm{g} / \mathrm{mL}$ ) of dry extract and fractions of leaves of $R$. sativus var. oleiferus.

\begin{tabular}{lcc}
\hline Samples & Percentages of DPPH radical scavenging* & Percentages of ferric ions reduction* \\
\hline EF & $26,48 \pm 0,4^{\mathrm{a}}$ & $6,49 \pm 0,28^{\mathrm{a}}$ \\
FrHex & $47,70 \pm 0,1^{\mathrm{c}}$ & $10,54 \pm 0,29^{\mathrm{d}}$ \\
FrAcOEt & $83,45 \pm 0,5^{\mathrm{g}}$ & $11,34 \pm 0,29^{\mathrm{e}}$ \\
FrBuOH & $57,20 \pm 0,3^{\mathrm{d}}$ & $10,71 \pm 0,29^{\mathrm{d}}$ \\
FrAq & $40,16 \pm 0,3^{\mathrm{b}}$ & $8,33 \pm 0,36^{\mathrm{b}}$ \\
Quercetina & $81,44 \pm 0,2^{\mathrm{f}}$ & - \\
Ácido Áscórbico & $90,43 \pm 0,3^{\mathrm{h}}$ & $20,53 \pm 0,51^{\mathrm{f}}$ \\
BHT & $63,7 \pm 0,10^{\mathrm{e}}$ & $9,13 \pm 0,28^{\mathrm{c}}$ \\
\hline
\end{tabular}

Legend: EF: dry extract of the leaves; FrHex: hexane fraction; FrAcOEt: ethyl acetate fraction; FrBuOH: butanol fraction; FrAq: aqueous fraction; BHT: butylated hydroxytoluene.

*Means with different letters in the same column are significantly different (Scott and Knott, $P<0.05$ ).

In previous studies with plants belonging to the Brassicaceae, the percentages of DPPH radical scavenged were found ranging from $14 \%$ to $23 \%$ in extracts of rocket (E. sativa) at a concentration of $0.1 \mathrm{mg} / \mathrm{mL}$ (ARBOS et al., 2010), $51.05 \%$ in broccoli extracts (B. oleracea var. italica), $29.06 \%$ in a radish extract ( $R$. sativus L. var. radicle) (MELO; FARIA, 2014) and $57.7 \%$ in essential oils of leaves of Eruca vesicaria (HICHRI et al., 2019), results lower than those obtained in the ethyl acetate fraction of this study.

The reducing power method complements the antiradical activity assessment, since it evaluates the capability of the samples in reducing ferric ions into ferrous ions by phenolic hydroxyls (ROGINSKY; LISSI, 2005). The test results confirm the samples can inhibit the oxidative damages, since the ferric ions are catalyzers of the formation of radical species (LLESUY, 2002).

\section{Evaluation of the antimicrobial activity}

The dry extract of the leaves of $R$. sativus var. oleiferus presented larger inhibition zones of microbial growth against $B$. subtilis, and this difference was significantly superior to those produced by the fractions $(P<0.05)$ (Table 4$)$. 
Study and evaluation...

SILVA, A. F. et al.

Table 4. The averages values of inhibition zones of microbial growth $(\mathrm{mm})$ of dry extract and fractions of leaves of $R$. sativus var. oleiferus evaluated by the agar diffusion method.

\begin{tabular}{|c|c|c|c|c|c|c|c|}
\hline \multirow[b]{2}{*}{ Microorganisms } & \multicolumn{7}{|c|}{ Averages inhibition zones $(\mathrm{mm})^{*}$} \\
\hline & $\mathrm{EF}$ & FrHex & FrAcOEt & FrBuOH & FrAq & $\mathrm{Cl}$ & $\mathrm{Ag}$ \\
\hline \multicolumn{8}{|l|}{ Gram-positive } \\
\hline B. subtilis & $18,67^{\mathrm{d}}$ & $9,00^{b}$ & $9,34^{\mathrm{b}}$ & $6,00^{b}$ & $5,30^{\mathrm{b}}$ & $28,00^{\mathrm{e}}$ & $0,00^{\mathrm{a}}$ \\
\hline B. cereus & $18,00^{\mathrm{c}}$ & $0,00^{\mathrm{a}}$ & $9,34^{\mathrm{b}}$ & $5,60^{\mathrm{b}}$ & $0,00^{\mathrm{a}}$ & $27,34^{\mathrm{e}}$ & $0,00^{\mathrm{a}}$ \\
\hline M. luteus & $10,67^{b}$ & $0,00^{\mathrm{a}}$ & $9,67^{\mathrm{b}}$ & $0,00^{\mathrm{a}}$ & $0,00^{\mathrm{a}}$ & $34,67^{\mathrm{f}}$ & $0,00^{\mathrm{a}}$ \\
\hline E. faecalis & $9,34^{\mathrm{b}}$ & $0,00^{\mathrm{a}}$ & $7,34^{\mathrm{b}}$ & $0,00^{\mathrm{a}}$ & $0,00^{\mathrm{a}}$ & $19,67^{\mathrm{d}}$ & $0,00^{\mathrm{a}}$ \\
\hline S. aureus & $13,00^{\mathrm{c}}$ & $8,00^{\mathrm{b}}$ & $9,34^{\mathrm{b}}$ & $0,00^{\mathrm{a}}$ & $0,00^{\mathrm{a}}$ & $27,34^{\mathrm{e}}$ & $0,00^{\mathrm{a}}$ \\
\hline \multicolumn{8}{|l|}{ Gram-negative } \\
\hline E. coli & $0,00^{\mathrm{a}}$ & $0,00^{\mathrm{a}}$ & $0,00^{\mathrm{a}}$ & $0,00^{\mathrm{a}}$ & $0,00^{\mathrm{a}}$ & $21,34^{\mathrm{d}}$ & $0,00^{\mathrm{a}}$ \\
\hline P. aeruginosa & $0,00^{\mathrm{a}}$ & $0,00^{\mathrm{a}}$ & $0,00^{\mathrm{a}}$ & $0,00^{\mathrm{a}}$ & $0,00^{\mathrm{a}}$ & $21,34^{\mathrm{d}}$ & $0,00^{\mathrm{a}}$ \\
\hline P. mirabilis & $0,00^{\mathrm{a}}$ & $0,00^{\mathrm{a}}$ & $0,00^{\mathrm{a}}$ & $0,00^{\mathrm{a}}$ & $0,00^{\mathrm{a}}$ & $17,00^{\mathrm{c}}$ & $0,00^{\mathrm{a}}$ \\
\hline S. typhimurium & $0,00^{\mathrm{a}}$ & $0,00^{\mathrm{a}}$ & $0,00^{\mathrm{a}}$ & $0,00^{\mathrm{a}}$ & $0,00^{\mathrm{a}}$ & $21,34^{\mathrm{d}}$ & $0,00^{\mathrm{a}}$ \\
\hline E. cloacae & $0,00^{\mathrm{a}}$ & $0,00^{\mathrm{a}}$ & $0,00^{\mathrm{a}}$ & $0,00^{\mathrm{a}}$ & $0,00^{\mathrm{a}}$ & $11,67^{\mathrm{b}}$ & $0,00^{\mathrm{a}}$ \\
\hline \multicolumn{8}{|l|}{ Fungi } \\
\hline S. cerevisae & $0,00^{\mathrm{a}}$ & $0,00^{\mathrm{a}}$ & $0,00^{\mathrm{a}}$ & $0,00^{\mathrm{a}}$ & $0,00^{\mathrm{a}}$ & $15,34^{\mathrm{c}}$ & $0,00^{\mathrm{a}}$ \\
\hline C. albicans & $0,00^{\mathrm{a}}$ & $0,00^{\mathrm{a}}$ & $0,00^{\mathrm{a}}$ & $0,00^{\mathrm{a}}$ & $0,00^{\mathrm{a}}$ & $15,67^{\mathrm{c}}$ & $0,00^{\mathrm{a}}$ \\
\hline \multicolumn{8}{|l|}{ Mycobacteria } \\
\hline M. tuberculosis & $0,00^{\mathrm{a}}$ & $0,00^{\mathrm{a}}$ & $0,00^{\mathrm{a}}$ & $0,00^{\mathrm{a}}$ & $0,00^{\mathrm{a}}$ & $20,00^{\mathrm{b}}$ & $0,00^{\mathrm{a}}$ \\
\hline M. bovis & $0,00^{\mathrm{a}}$ & $0,00^{\mathrm{a}}$ & $0,00^{\mathrm{a}}$ & $0,00^{\mathrm{a}}$ & $0,00^{\mathrm{a}}$ & $20,00^{\mathrm{b}}$ & $0,00^{\text {a }}$ \\
\hline
\end{tabular}

Legend: EF: dry extract of the leaves; FrHex: hexane fraction; FrAcOEt: ethyl acetate fraction; FrBuOH: butanol fraction; FrAq: aqueous fraction; $\mathrm{Cl}$ : Chlorhexidine $0.12 \%$; $\mathrm{Ag}$ : Distilled water.

* Means with different letters in the same column are significantly different (Scott and Knott, $P<0.05$ ).

The antibacterial activity is related to bioactive compounds present in the dry extract and the fractions of the leaves. However, which chemical compounds, alone or in combination, are active can not be determined in this study. There is a possibility that the compounds act synergistically against B. subtilis, B. cereus, M. luteus, S. aureus and E. faecalis, because the dry extract of the leaves produced larger inhibition zones compared to their fractions.

The antimicrobial activity of flavonoids can be attributed to their role causing changes in the physical-chemical properties of cell membranes, such as decreasing their fluidity (TSUCHIYA, 2010), activity of flavonoids can be attributed to the inhibition of nucleic acid synthesis, energy metabolism and cell wall synthesis (TIM; LAMBB, 2011).

The dry extract and the fractions of the leaves of fodder turnip proved to be active only against gram-positive bacteria. This absence of antimicrobial activity is likely due to different actions of the active compounds of the extract on the walls or cell membranes of the microorganisms, since these exhibit variations in their chemical constitutions cells. The cell wall of gram-negative microorganisms is more complex, and has an additional outer membrane with a second lipid bilayer which strongly adheres to the peptidoglycan layer, giving greater stiffness and antigenicity (GUIMARÃES; MOMESSO; PUPO, 2010). The high concentration of high molecular weight lipids present in the cell wall of mycobacteria acts as a barrier for polar compounds (ARANTES et al., 2005). The cytoplasmic membranes of fungi include steroids, lipids and also proteins (TORTORA; FUNKE; CASE, 2012). This may explain the resistance of these microorganisms to hydroethanolic extracts. However, several studies have demonstrated the antimicrobial capacity of different extracts of the plant against some of these microorganisms (SHUKLA et al., 2011; AHMAD et al., 2012; UMAMAHESWARI; AJITH; ASOKKUMAR, 2012; JANJUA; SHAHID; ABBAS, 2013; CHIHOUB et al., 2019; DUY et al., 2019; IYDA et al., 2019), suggesting that future experiments with extracts of the fodder turnip of different polarities are promising.

The lowest MIC values (Table 5) were obtained against $M$. luteus, and the ethyl acetate fraction showed the lowest MIC against this microorganism, followed by the aqueous and butanol fractions. The ethyl acetate fraction was shown to be more effective, with MICs between 0.1 and $12.5 \mathrm{mg} / \mathrm{mL}$. 
Table 5. Determinations of Minimum Inhibitory Concentration (MIC) $(\mathrm{mg} / \mathrm{mL})$ of dry extract and fractions of leaves of $R$. sativus var. oleiferus.

\begin{tabular}{lccccc}
\hline \multirow{2}{*}{ Bacteria } & \multicolumn{5}{c}{ Minimum Inhibitory Concentration $(\mathrm{mg} / \mathrm{mL})$} \\
\cline { 2 - 6 } & $\mathrm{EF}$ & FrHex & FrAcOEt & FrBuOH & FrAq \\
\hline B. subtilis & 3,12 & 6,25 & 0,4 & 3,12 & 3,12 \\
B. cereus & 12,5 & 3,12 & 0,8 & 1,56 & 3,12 \\
M. luteus & 12,5 & nd & 0,1 & 0,4 & 0,2 \\
E. faecalis & 12,5 & 12,5 & 12,5 & 12,5 & 12,5 \\
S. aureus & 6,25 & nd & 0,1 & 3,12 & 3,12 \\
\hline
\end{tabular}

Legend: EF: dry extract of the leaves; FrHex: hexane fraction; FrAcOEt: ethyl acetate fraction; FrBuOH: butanol fraction; FrAq: aqueous fraction; nd: not detected at maximum concentration tested $(12.5 \mathrm{mg} / \mathrm{mL})$.

Some techniques used for antimicrobial evaluation may also lead to false negative results. The agar diffusion test, for instance, is only efficient for polar substances, allowing the diffusion of these through the culture medium. In addition, factors such as the presence of bacterial enzymes, the composition of the medium, the diffusion of the substance in the medium, the inoculum density, the time and temperature of incubation, the stability of substances and the molecular mass may hinder diffusion in the medium (SILVEIRA et al., 2009), which can prevent the contact of the extracts with microorganisms, leading to negative results. However, the plate microdilution assay allows direct contact of the extract with the microorganisms, avoiding possible limitations of the agar diffusion method.

The extracts that present MIC less than 100 $\mu \mathrm{g} / \mathrm{mL}$ can be considered to have good antimicrobial activity, MIC between 100-500 $\mu \mathrm{g} / \mathrm{mL}$ are moderately active, MIC between 500 $1000 \mu \mathrm{g} / \mathrm{mL}$ are very active and higher MIC than $1000 \mu \mathrm{g} / \mathrm{mL}$ are considered inactive (HOLETS et al., 2002; FABRY et al., 2008). Thus, from table 5, it can be seen that ethyl acetate fractions, followed by aqueous and butanol fractions showed the best antimicrobial activity, as demonstrated by their MIC in the range $100-800 \mu \mathrm{g} / \mathrm{mL}$.

In a study with aqueous extracts of the fruits of $R$. sativus L. MIC values of $5 \mathrm{mg} / \mathrm{mL}$ against $S$. aureus were found (EDZIRI et al., 2012), higher than those obtained in the ethyl acetate, butanol and aqueous fractions of the leaves of $R$. sativus var. oleiferus. Jadoun et al. (2016) obtained MIC values of $0.5 \mathrm{mg} / \mathrm{mL}$ for the same microorganism, however using sulfur compounds isolated from seeds of $R$. sativus L. Chihoub et al. (2019) obtained MIC of 20 $\mathrm{mg} / \mathrm{mL}$ for $E$. faecalis using hydroethanolic extracts $80 \%$ of $R$. sativus L leaves. Therefore, the results obtained highlight the fodder turnip as a source of antibacterial compounds.

\section{Correlation analyze}

The results of the correlation analyze between the main constituents detected and the biological activities (Table 6) showed values of positive $\mathrm{r}$, according to the classification of Callegari-Jaques (2003).

Table 6. Statistical analysis of the correlation between the parameters evaluated.

\begin{tabular}{ll}
\hline Correlation & r** \\
\hline Antimicrobian activity & 0,40 \\
MIC x Phenolic & 0,33 \\
MIC x Flavonoids & \\
Antioxidant activity "in vitro" & 0,80 \\
DPPH• method x Phenolic & 0,77 \\
DPPH• method x Flavonoids & 0,70 \\
Reducing power method x Phenolic & 0,64 \\
Reducing power method x Flavonoids
\end{tabular}

Legend: $r=$ correlation coefficient; MIC $=$ Minimum Inhibitory Concentration; DPPH $\bullet=$ radical DPPH.

**According to the classification of Callegari-Jacques (2003): $0.00<\mathrm{r}<0.30$ shows weak correlation; $0.30<\mathrm{r}<0.60$, shows moderate correlation; $0.60<\mathrm{r}<0.90$, shows strong correlation and $0.90<\mathrm{r}<1.00$ shows a strong correlation between the evaluated parameters. 
The analyses showed positive correlations between the lowest minimum inhibitory concentration values obtained and the highest amounts of phenols and flavonoids in the extracts and fractions (Table 6). This can be considered as a moderate to correlation (CALLEGARI-JACQUES, 2003) between the presence of these metabolites and the best antimicrobial activity values. This indicates that phenolic compounds, particularly flavonoids, have an important role in the antimicrobial activity of the dry extract and the fractions of leaves of $R$. sativus var. oleiferus. However it is likely that the activity is not only related to this class of secondary metabolites.

The analysis of the correlation between the highest values in the antiradical activity measured by DPPH radical scavenging and the highest reducing power with the highest amounts of total phenols and flavonoids in the dried extract and the evaluated fractions also showed positive $r$ values (Table 6), there is a strong correlation (CALLEGARI-JACQUES, 2003) between these metabolites and the highest values of antioxidant activity in vitro. This shows that phenolic compounds, especially flavonoids, are the main compounds responsible for the antioxidant activity. Similar correlations were obtained in the study by $\mathrm{Li}$ et al. (2018) with 12 cruciferous vegetables.

Chihoub et al. (2019) in their study with $80 \%$ of hydroethanolic extract from $R$. sativus $\mathrm{L}$. leaves concluded that the phenolic compounds are strongly correlated to the antioxidant and the antimicrobial activity.

\section{Cytotoxicity}

The extract and fractions not shown cytotoxic for peritoneal murinos macrophages until the highest concentration evaluated $(160 \mu \mathrm{g} / \mathrm{mL})$. A positive aspect in studies of cytotoxic activity appears in search of potentially anticancer substances. Pocasap, Weerapreeyakul and Barusrux (2013) evaluated the antitumor effect of the extract of $R$. sativus var. caudatus against a colon cancer cell line HCT116, by MTT assay and the results showed high citotoxicity against extract these cells, with CC50 of $9.42 \pm 0.46 \mu \mathrm{g} / \mathrm{ml}$. To view more cytotoxic trials with the species $R$. sativus var. oleiferus can lead to relevant results.

\section{CONCLUSION}

The potential antioxidant and antimicrobial actions of the extract and the fractions of leaves of $R$. sativus var. oleiferus, and the ethyl acetate fraction was promising for further studies. Moreover, it revealed that concentrations of the major components detected showed positive correlations with the biological activities evaluated. The samples did not show cytotoxicity until the highest concentration evaluated.

\section{ACKNOWLEDGEMENTS}

The authors are grateful to Fundação de Amparo à Pesquisa do Estado de Minas Gerais (FAPEMIG) and Federal University of Alfenas (UNIFAL-MG) for financial support and to Prof. Dr. Wagner Vilegas and Dr. Marcelo José Dias (UNESP-Araraquara) for the analyzes with mass spectrometry.

RESUMO: O rabanete (Raphanus sativus L.) é um vegetal da família Brassicaceae cultivado em todo o mundo e possui diversas propriedades medicinais. Suas atividades biológicas estão relacionadas aos vários metabólitos secundários presentes na espécie, especialmente os compostos fenólicos. Desta forma, os objetivos deste estudo foram realizar análises químicas e avaliar as atividades antioxidante e antimicrobiana do extrato seco e das frações das folhas de $R$. sativus var. oleiferus Metzg. As amostras foram analisadas em espectrômetro de massas e o potencial antioxidante foi avaliado pelos métodos do radical DPPH (2,2-difenil-1picrilhidrazila) e do poder redutor. A atividade antimicrobiana foi determinada pelos métodos de difusão em ágar e da microdiluição. Observou-se que os fenóis totais se concentraram na fração butanólica $(121,27 \mathrm{mg}$ EAG/g), enquanto que e os teores de flavonoides concentraram-se na fração acetato de etila $(98,02 \mathrm{mg} \mathrm{EQ} / \mathrm{g})$. A fração acetato de etila apresentou os melhores resultados antioxidantes, com porcentagem de sequestro dos radicais DPPH de 83,45\% e com porcentagem de redução dos íons férrico de 11,34\%. A análise da atividade antimicrobiana revelou que o extrato seco teve maior média de halos de inibição frente ao Bacillus subtilis (18,67 mm). Os menores valores da concentração inibitória mínima foram para Micrococcus luteus, sendo que a fração acetato de etila demonstrou menor concentração inibitória mínima $(0,1 \mathrm{mg} / \mathrm{mL})$ para esse microorganismo. Houve uma forte correlação entre a atividade antioxidante e o teor de fenóis e de flavonoides. Os resultados demonstraram potenciais ações antioxidante e antimicrobiana do extrato e das frações avaliados, sendo a fração acetato de etila promissora para estudos posteriores. 
PALAVRAS-CHAVE: Nabo forrageiro. Brassicaceae. Compostos fenólicos. Plantas Medicinais.

\section{REFERÊNCIAS}

AHMAD, F.; HASAN, I.; CHISHTI, D.K.; AHMAD, H. Antibacterial activity of Raphanus sativus Linn. seed extract. Global Journal of Medical Research, v. 12, n. 2, p. 25-33, 2012.

ALQASOUMI, S.; AI-HOWIRINY, T.; RAFATULLAH, S. Gastroprotective effect of radish (Raphanus Sativus L.) on experimental gastric ulcer models in rats. Farmácia, v. 56, n. 2, p. 204-214, 2008.

ARANTES, V.P.; SATO, D.N.; VILEGAS, W.; SANTOS, L.C.; LEITE, C.Q.F. Plantas do cerrado brasileiro com atividade contra Mycobacterium fortuitum. Revista de Ciências Farmacêuticas Básica e Aplicada, v. 26, n. 3, p. 195-198, 2005.

ARBOS, K.A.; FREITAS, R.J.S.; STERTZ, S.C.; DORNAS, M.F. Atividade antioxidante e teor de fenólicos totais em hortaliças orgânicas e convencionais. Ciência e Tecnologia de Alimentos, v. 30, n. 2, p. 501-506, 2010. https://doi.org/10.1590/S0101-20612010000200031

ARUNA, G.; YERRAGUNI, V. G.; RAJU, A. B. Phytochemistry and Pharmacology ofraphanussativus. International Journal of Drug Formulation and Research, v. 3, n. 1, p. 43-52, 2012.

BANIHANI, S. A. Radish (Raphanus sativus) and Diabetes. Nutrients, v. 9, n. 1014, p. 1-9, 2017. https://doi.org/10.3390/nu9091014

CALLEGARI-JACQUES, S. M. Bioestatística: princípios e aplicações. Porto Alegre: Artemed, 2003, 255 p.

CHIHOUB, W.; DIASA, M.I.; BARROSA, L.; CALHELHA, R.C; ALVESA, M.J.; HARZALLAH-SKHIRIB, F.; FERREIRA, I.C.F.R. Valorisation of the green waste parts from turnip, radish and wild cardoon: Nutritional value, phenolic profile and bioactivity evaluation. Food Research International, v. 126, p. 1-10, 2019. https://doi.org/10.1016/j.foodres.2019.108651

CHOROL S. Antioxidant Content in Different Parts of Radish (Raphanus sativus L.) from Cold Arid Ladakh region of Trans- Himalaya (Jammu and Kashmir). Pharmacognosy Journal, v. 11, n. 5, p. 1064-1070, 2019. http://www.phcogj.com/v11/i5 https://doi.org/10.5530/pj.2019.11.166

CLSI-CLINICAL AND LABORATORY STANDARDS INSTITUTE. Methods for dilution antimicrobial susceptibility tests for bacteria that grow aerobically:Approved standard. 6 ed. CLSI M7-A6. Wayne, Pensilvânia, USA, 2003.

CLSI-CLINICAL AND LABORATORY STANDARDS INSTITUTE. Reference Method for Broth Dilution Antifungal Susceptibility Testing of Yeasts: Approved Standard. 3 ed. CLSI M27-A3. Wayne, Pensilvânia, USA, 2008.

CLSI-CLINICAL AND LABORATORY STANDARDS INSTITUTE. Reference method for antifungal disk diffusion susceptibility testing of yeasts: Approved Guideline. 2 ed. CLSI M44-A2. Wayne, Pensilvânia, USA, 2009.

CLSI-CLINICAL AND LABORATORY STANDARDS INSTITUTE. Susceptibility Testing of Mycobacteria, Nocardie, and Pther Aerobic Actinomycetes: Approved Standard. 2 ed. CLSI M24-A2. Wayne, Pensilvânia, USA, 2011.

DEVARAJ, V. C.; KRISHNA, B. G.; VISWANATHA, G. L. Simultaneous determination of quercetin, rutin and kaempferol in the leaf extracts of Moringa oleifera Lam. and Raphanus sativus Linn. by liquid 
chromatography-tandem mass spectrometry. Chinese Journal of Integrative Medicine, v. 19, n. 3, p. 10221030, 2011. https://doi.org/10.3736/jcim20110914

DUY, H. H.; NGOC, P. T. K.; ANH, L. T. H.; DAO, D. T. A.; NGUYEN, D. C.; THAN, A. V. T. In Vitro antifungal efficacy of white radish (Raphanus sativus $\mathrm{L}$.) root extract and application as a natural preservative in sponge cake. Processes, v. 7, n. 9, p. 1-18, 2019. https://doi.org/10.3390/pr7090549

EDZIRI, H.; AMMAR, S.; SOUAD, L., MAHJOU, M. A.; MASTOURI, M.; AOUNI, M.; MIGHRI, Z; VERSCHAEVED, L. In vitro evaluation of antimicrobial and antioxidant activities of some Tunisian vegetables. South African Journal of Botany, v. 78, p. 252-256, 2012.

https://doi.org/10.1016/j.sajb.2011.09.012

EVELINE AND PASAU, R. L. Antioxidant activity and stability of radish bulbs (Raphanus sativus L.) crude extract. L. IOP Conference Series: Earth and Environmental Science, v. 292, n. 1, p.1-8, 2019. https://doi.org/10.1088/1755-1315/292/1/012036

FABRY, W.; OKEMO, P.O.; ANSORG, R. Antibacterial actity of east African medicinal plants. Journal of Ethnopharmacology, v. 60, n. 1, p. 79-84, 2008. https://doi.org/10.1016/S0378-8741(97)00128-1

GATES, P. J.; LOPES, N. P. Characterisation of Flavonoid Aglycones by Negative Ion Chip-Based Nanospray Tandem Mass Spectrometry. International Journal of Analytical Chemistry, v. 2012, n. 2012, p.1-7, 2012. http://dx.doi.org/10.1155/2012/259217

GOYENECHE, R.; ROURA, S.; PONCE, A.; VEGA-GÁLVEZ, A.; QUISPE-FUENTES, I.; URIBE, E.; DI SCALA, K. Chemical characterization and antioxidant capacity of red radish (Raphanus sativus L.) leaves and roots. Journal of Functional Foods, v. 16, p. 256-264, 2015. https://doi.org/10.1016/j.jff.2015.04.049

GUIMARÃES, D. O.; MOMESSO, L. S.; PUPO, M. P. Antibiotics: therapeutic importance and perspectives for the discovery and development of new agents. Química Nova, v. 33, n. 3, p. 667-679, 2010. https://doi.org/10.1590/S0100-40422010000300035

GUTIERREZ, R. M.; PEREZ, R. L. Raphanus sativus (radish): their chemistry and biology. Scientific World Journal, v. 4, n. 8, p. 811-833, 2004. http://dx.doi.org/10.1100/tsw.2004.131

HICHRI, F.; OMRI HICHRI, A.; MAHA, M.; SAAD MANA HOSSAN, A.; FLAMINI, G.; BEN JANNET, H. Chemical Composition, Antibacterial, Antioxidant and in Vitro Antidiabetic Activities of Essential Oils from Eruca vesicaria. Chemistry \& Biodiversity, v. 16, p. 1-10, 2019.

https://doi.org/10.1002/cbdv.201900183

HOLETS, F. B.; PESSINI, G. L.; SANCHES, N. R.; CORTEZ, D. A. G. Screening of some slants used in the Brazilian folk medicine for the treatment of infectious diseases. Memorias do Instituto Oswaldo Cruz, v. 97, n. 7, p. 1027-1031, 2002. http://dx.doi.org/10.1590/S0074-02762002000700017

IYDA, J. H.; FERNANDES, A. F.; FERREIRA, F. D.; ALVES, M. J.; PIRES, T. C. S. P.; BARROS, L.; AMARAL, J.S.; FERREIRA, I.C.F.R. Chemical composition and bioactive properties of the wild edible plant Raphanus raphanistrum L. Food Research International, v. 121, p. 714-722, 2019. https://doi.org/10.1016/j.foodres.2018.12.046

JADOUN, J.; YAZBAK, A.; RUSHRUSH, S.; RUDY, A.; AZAIZEH, H. Identification of a New Antibacterial Sulfur Compound from Raphanus sativus seeds. Journal of Evidence-Based Complementary \& Alternative Medicine, v. 2016, n. 2016, p. 1-7, 2016. http://dx.doi.org/10.1155/2016/9271285

JAHANGIR, M.; KIM, H. K.; CHOI, Y. H. VERPOORTE, R. Health-Affecting Compounds in Brassicaceae. Comprehensive Reviews in Food Science and Food Safety, v. 8, n. 2, p. 31-43, 2009.

https://doi.org/10.1111/j.1541-4337.2008.00065.x 
JANJUA, S.; SHAHID, M.; ABBAS, F.I. Phytochemical analysis and in vitro antibacterial activity of root peel extract of Raphanus sativus L. var. niger. Advancement in Medicinal Plant Research, v. 1, n. 1, p. 1-7, 2013.

KALIA, K.; SHARMA, K.; SINGH, H. P.; SINGH, B. Effects of extraction methods on phenolic contents and antioxidant activity in aerial parts of Potentilla atrosan- guinea Lodd. and quantification of its phenolic

constituints by RP-HPLC. Journal of Agricultural and Food Chemistry, v. 56, n. 21, p. 10129-10134, 2008. https://doi.org/10.1021/jf802188b

KIM, J. K.; BASKAR, T. B.; PARK, S. U. Total Phenolic and Flavonoid Contents and Antioxidant Activities of Two Raphanus sativus L. cultivars (Cherry Belle and Valentine). Biosciences Biotechnology Research Asia, v. 13, n. 1, p. 31-36, 2016. http://dx.doi.org/10.13005/bbra/1999

LI, Z; LEE, H.; LIANG, X.; LIANG, D.; WANG, Q.; HUANG, D.; ONG, C. Profiling of Phenolic Compounds and Antioxidant Activity of 12 Cruciferous Vegetables. Molecules, v. 23, n. 5, 1139, 2018.

https://doi.org/10.3390/molecules23051139

LLESUY, S. F. Introducción y espécies activas de oxígeno. In: MARRONI, N.P. et al. Estresse oxidativo e antioxidantes. Porto Alegre: Editora Ulbra, 2002. p. 21-32.

LUO, X.; ZHANG, H.; DUAN, Y.; CHEN, G. Protective effects of radish (Raphanus sativus L.) leaves extract against hydrogen peroxide-induced oxidative damage in human fetal lung fibroblast (MRC-5) cells.

Biomedicine \& Pharmacotherapy, v. 103, p. 406-414, 2018. https://doi.org/10.1016/j.biopha.2018.04.049

MANIVANNAN, A.; KIM, J.; KIM, D.; LEE, E.; LEE, H.. Deciphering the Nutraceutical Potential of Raphanus sativus-A Comprehensive Overview. Nutrients, v. 11, n. 402, p. 1-15, 2019.

https://doi.org/10.3390/nu11020402

MELO, C. M. T.; FARIA, J. V. Composição centesimal, compostos fenólicos e atividade antioxidante em partes comestíveis não convencionais de seis olerícolas. Bioscience Journal, v. 30, n. 1, p. 93-100, 2014.

MENEZES, T. O. A.; ALVES, A. C. B. A.; VIEIRA, J. M. S.; MENEZES, S. A. F.; ALVES, B. P.;

MENDONÇA, L. C. V. In vitro evaluation of the anti-fungi activity of essential oils and plant extracts present in the amazon region about the strain of Candida albicans. Revista de Odontologia da UNESP, v. 38, n. 3, p.184-191, 2009.

PARK, C. H; BASKAR, T. B.; PARK, S.; KIM, S. J.; ARASU, M. V.; AL-DHABI, N. A.; KIM, J. K.; PARK, S. U. Metabolic Profiling and Antioxidant Assay of Metabolites from Three Radish Cultivars (Raphanus sativus). Molecules, v. 21, n. 2, p. 157, 2016. https://doi.org/10.3390/molecules21020157

PARK, H. J.; SONG, M. Leaves of Raphanus sativus L. Shows Anti-Inflammatory Activity in LPS-Stimulated Macrophages via Suppression of COX-2 and iNOS Expression. Preventive Nutrition and Food Science, v. 22, n. 1, p. 50-55, 2017. https://doi.org/10.3746/pnf.2017.22.1.50

PARK, Y. J.; MOON, C.; KANG, J. H.; CHOI, T. J. Antiviral effects of extracts from Celosia cristata and Raphanus sativus roots against viral hemorrhagic septicemia virus. Archives of Virology, v. 162, n. 6, p. 17111716, 2017. https://doi.org/10.1007/s00705-017-3270-z

PEREIRA, I. O.; MARQUES, M. J.; PAVAN, A. L. R.; CODONHO, B. S.; BARBIÉRI, C. L.; BEIJO, L. A.; DORIGUETTO, A. C.; MARTIN, E. C. D.; SANTOS, M. H. Leishmanicidal activity of benzophenones and extracts from Garcinia brasiliensis Mart. Fruits. Phytomedicine, v. 17, p. 339-345, 2010.

https://doi.org/10.1016/j.phymed.2009.07.020

PEREIRA, R. J.; CARDOSO, M. G. Vegetable secondary metabolites and antioxidants benefits. Journal of Biotechnology and Biodiversity, v. 3, n. 4, p.146-152, 2012. 
POCASAP, P.; WEERAPREEYAKUL, N.; BARUSRUX, S. Cancer preventive effect of Thai rat-tailed radish (Raphanus sativus L. var. caudatus Alef.). Journal of functional foods, v. 5, p. 1372-1381, 2013. https://doi.org/10.1016/j.jff.2013.05.005

PODSEDEK, A. Natural antioxidants and antioxidant capacity of Brassica vegetables: a review. Food Science and Technology, v. 40, n. 1, p.1-11, 2007. https://doi.org/10.1016/j.lwt.2005.07.023

PRISTA, L. N.; ALVES, A. C.; MORGADO, R. M. R. Técnica Farmacêutica e Farmácia Galênica. 4 ed. Lisboa: Fundação Calouste Gulbenkian, 1992, 1134p.

RANA, M. I.; ALI, M. E.; DALIA, O. S.; EL MOATAZ, B. E. N.; ABD EL-RAHMAN, O. E. L.; SEHAM, S. H. E. HPLC-DADMS/MS profiling of phenolics from Securigera securidaca flowers and its anti-hyperglycemic and anti-hyperlipidemic activities. Revista brasileira de farmacognosia, v. 25, n. 2, p. 134-141, 2015.

https://doi.org/10.1016/j.bjp.2015.02.008

RICARDO, L. L; BERNARDI, D. I.; MANTOVANELLI, G. C.; MORENO, B. P.; MITO, M. S.; SILVA, A. A.; OLIVEIRA, R. S. O.; ISHII- IWAMOTOB, E. L.; SARRAGIOTTO, M. H.; ALDOQUI, D.

C. Phytochemical investigation and phytotoxic activity of aerial parts of oilseed radish (Raphanus sativus var. oleifer Stokes). Biochemical Systematics and Ecology, v. 78, p. 52-58, 2018.

https://doi.org/10.1016/j.bse.2018.03.009

ROGINSKY, V.; LISSI, E. A. Review of methods to determine chain- breaking antioxidant activity in food. Food Chemistry, v. 92, n. 2, p. 235-254, 2005. https://doi.org/10.1016/j.foodchem.2004.08.004

SCOTT, A. J.; KNOTT, M. Cluster analysis method for grouping means in the analysis of variance.

Biometrics, v.30, n. 3, p. 507-512, 1974. https://doi.org/10.2307/2529204

SHIN, T.; AHN, M.; KIM, G. O.; PARK, S. U. Biological activity of various radish species. Oriental Pharmacy and Experimental Medicine, v. 15, n. 2, p. 105-111, 2015. https://doi.org/10.1007/s13596-0150183-9

SHUKLA, S.; CHATTERJI, S.; YADAV, D. K.; WATAL, G. Antimicrobial efficacy of Raphanus sativus root juice. International Journal of Pharmacy and Pharmaceutical Sciences, v. 3, n. 5, p. 89-92, 2011.

SILVA, L. R.; VALE, L. M.; FELÍCIO, C. B. Flavonoids: Chemical composition, medical actions and toxicity. Acta Toxicológica Argentina, v. 23, n.1, p. 36-43, 2015.

SILVEIRA, L. M. S.; MESQUITA, J. S.; CRUZ, A. L. N.; MENDES, J. C. Metodologias de atividade antimicrobiana aplicadas a extratos de plantas: comparação entre duas técnicas de ágar difusão. Revista Brasileira de Farmácia, v. 90, n. 2, p. 124-128, 2009.

SINGLETON, V. L.; ORTHOFER, R.; LAMUELA-RAVENTOS, R. M. Analysis of total phenols and other oxidation substrates and antioxidants by means of Folin-Ciocalteau reagent. Methods in Enzymology, v.299, n., p. 152-178, 1999. https://doi.org/10.1016/S0076-6879(99)99017-1

SOUZA, V. C.; LORENZI, H. Botânica Sistemática-Guia ilustrado para identificação das famílias de Angiospermas da flora brasileira, baseado em APG II, Instituto Plantarum de Estudos da Flora Ltda. Nova Odessa, 2005. $640 \mathrm{p}$.

SOUZA-MOREIRA, T. M.; SALGADO, H. R. N.; PIETRO, R. C. L. R. Brazil in the context of plants and derivates quality control. Revista brasileira de farmacognosia, v. 20, n. 3, p. 435-440, 2010.

http://dx.doi.org/10.1590/S0102-695X2010000300023 
SUN, J.; LIANG, F.; BIN, Y.; LI, P.; DUAN, C. Screening non-colored phenolics in red wines using liquid chromatography/ultraviolet and mass spectrometry/mass spectrometry libraries. Molecules, v. 12, n. 3, p. 679693, 2007. https://doi.org/10.3390/12030679

TIM CUSHNIEA, T. P.; LAMBB, A. J. Recent advances in understanding the antibacterial properties of flavonoids. International Journal of Antimicrobial, v. 38, n. 2, p. 99-107, 2011. https://doi.org/10.1016/j.ijantimicag.2011.02.014

TORTORA, G. J.; FUNKE, B. R.; CASE, C. L. Microbiologia. 10 ed. Porto Alegre: Artmed, 2012, 964 p.

TSUCHIYA, H. Structure-dependent membrane interaction of flavonoids associated with their bioactivity. Food Chemistry, v. 120, n. 40, p. 1089-1096, 2010. https://doi.org/10.1016/j.foodchem.2009.11.057

UMAMAHESWARI, M.; AJITH, M. P.; ASOKKUMAR, K. In vitro angiotensin converting enzyme inhibitory and antioxidant activities of seed extract of Raphanus sativus Linn. European Journal of Experimental Biology, v.1, n. 1, p. 11-17, 2012. https://doi.org/10.15373/22778179/NOV2012/1

VALLVERDÚ-QUERALT, A.; REGUEIRO, J.; ALVARENGA, J. F. R.; MARTINEZ-HUELAMO, M.; LEAL, L. N.; LAMUELARAVENTOS, R. M. Characterization of the phenolic and antioxidant profiles of selected culinary herbs and spices: caraway, turmeric, dill, marjoram and nutmeg. Food Science and Technology, v. 35, n. 1, p. 189-195, 2015. http://dx.doi.org/10.1590/1678-457X.6580

VEIGA, J. V. F.; PINTO, A. C.; MACIEL, M. A. M. Medicinal plants: safe cure? Química Nova, v. 28, n. 3 , p. 519-528, 2005. http://dx.doi.org/10.1590/S0100-40422005000300026

WOLFENDER, J. L.; MAILLARD, M.; MARSTON, A.; HOSTETTMANN, K. Mass spectrometry of underivatised naturally occurrung glycosides. Phytochemical Analysis, v. 3, n. 5, p. 193-214, 1992. https://doi.org/10.1002/pca.2800030502

YEN, W. J.; CHANG, L. W.; DUH, P. D. Antioxidant activity of peanut seed testa and its antioxidative component, ethyl protocatechuate. Food Science and Technology, v.38, n. 3, p. 193-200, 2005.

https://doi.org/10.1016/j.lwt.2004.06.004

YILDRIM, A.; MAVI, A.; KARA, A. A. Determination of antioxidant and antimicrobial activies of Rumex crispus L. extracts. Journal of Agricultural and Food Chemistry, v. 499, n. 8, p. 4083-4089, 2001a. https://doi.org/10.1021/jf0103572

YILDRIM, A.; OKTAY, M.; BILALOGLU, V. The antioxidant activies of the leaves of Cydonia vulgaris. Turkish Journal of Medical Sciences, v. 31, n., p. 23-27, $2001 \mathrm{~b}$.

ZANUTTO, F. V.; BOLDRIN, P. K.; VARANDA, E. A. et al. Characterization of Flavonoids and Naphthopyranones in Methanol Extracts of Paepalanthus chiquitensis Herzog by HPLC-ESI-IT-MSn and Their Mutagenic Activity. Molecules, v.18, n., p. 244-262, 2013. https://doi.org/10.3390/molecules 18010244

ZECCA, A. G. D: Botânica Sistemática de Plantas de interesse agrícola 2008. Address of page: <https://pt.scribd.com/document/91297856/BOTANICA-Apostila-COMPLETA> Date accessed: September 23, 2013. 